\title{
Towards an aerosol classification scheme for future EarthCARE lidar observations and implications for research needs
}

\author{
S. Groß, ${ }^{\prime *}$ V. Freudenthaler, ${ }^{2}$ M. Wirth' and B. Weinzierl',2 \\ I Institut für Physik der Atmosphäre, Deutsches Zentrum für Luft- und Raumfahrt (DLR), 82234 Oberpfaffenhofen, Germany \\ ${ }^{2}$ Meteorologisches Institut, Ludwig-Maximilians-Universität, 80333 Munich, Germany
}

* Correspondence to:

S. Groß, Institut für Physik der

Atmosphäre, Deutsches

Zentrum für Luft- und Raumfahrt

(DLR), 82234 Oberpfaffenhofen,

Germany.

E-mail: Silke.Gross@dlr.de

Received: 28 August 2013

Revised: 8 April 2014

Accepted: 21 July 2014

\begin{abstract}
Owing to the high variability of aerosols, and their different impact on the Earth's climate system, aerosol type classification from satellite measurements is of high importance. Polarization sensitive lidar measurements on board the future Earth Clouds, Aerosols and Radiation Explorer (EarthCARE) satellite mission will provide information to distinguish different aerosol types. We analyze whether former classification schemes based on lidar measurements at $532 \mathrm{~nm}$ are applicable to EarthCARE measurements at $355 \mathrm{~nm}$. We compare coordinated lidar measurements at both wavelengths performed during five field experiments; adapt thresholds for aerosol classification with future spaceborne lidar measurements and identify limitations of the current state of knowledge.
\end{abstract}

Keywords: aerosols; EarthCARE; lidar; remote sensing; classification

\section{Introduction}

Aerosols are a fundamental part of the Earth's atmosphere with various impacts on the Earth's radiation budget and hydrological cycle. These numerous effects are not yet fully understood (Forster et al., 2007; Penner et al., 2011; Bond et al., 2013). A main reason is the large variability and the limited knowledge of the temporal and spatial distribution of the optical and microphysical properties of aerosols on global scales (Penner et al., 2001). In addition the sign and the magnitude of the radiative forcing strongly depend on the vertical layering of aerosols and the presence of clouds underneath the aerosol layers (Forster et al., 2007). To improve our understanding regular observations with high vertical and horizontal resolution are required. Spaceborne measurements with elastic backscatter lidar systems such as the Cloud-Aerosol Lidar with Orthogonal Polarization (CALIOP) system (Winker et al., 2007) on board the Cloud-Aerosol Lidar and Pathfinder Satellite Observations (CALIPSO) mission gather such altitude-resolved information. However, for the classification of different aerosol types assumptions are necessary (Omar et al., 2009) which may cause misclassification (Kacenelenbogen et al., 2011; Burton et al., 2013). Advanced lidar systems like polarization sensitive Raman lidar systems (Ansmann et al., 1992) or high spectral resolution lidar (HSRL) systems (Piironen and Eloranta, 1994; Esselborn et al., 2008) are capable of distinguishing different aerosol types as shown, e.g. by Groß et al. (2011a, 2013b), Weinzierl et al. (2011), and Burton et al. (2012), as they are capable of directly retrieving the lidar ratio without assumptions of a priori information. At the moment, these lidar systems are either airborne or ground-based, but the next generation satellite mission of the European Space Agency (ESA) together with the Japan Aerospace Exploration Agency (JAXA), the Earth Clouds, Aerosols and Radiation Explorer (EarthCARE) mission will be equipped with a polarization sensitive HSRL system (ATLID - Atmospheric Lidar) operating at $355 \mathrm{~nm}$. Current aerosol classification schemes (Burton et al., 2012; Groß et al., 2013b) were developed based on airborne HSRL measurements at $532 \mathrm{~nm}$. It is an open question how the present classification schemes can be transferred to measurements with the ATLID system on EarthCARE at $355 \mathrm{~nm}$. In this work, we present an analysis of the wavelength dependence of the lidar ratio $S_{\mathrm{p}}$ and the particle linear depolarization ratio $\delta_{\mathrm{p}}$, required for an aerosol classification with ATLID measurements, for five main aerosol types and aerosol mixtures of the Earth's atmosphere - mineral dust, mineral dust mixtures, marine aerosols, biomass burning mixtures and volcanic ash.

\section{Methods}

\section{I. Data basis}

In this study, we use data from five different field experiments: the Lindenberg Aerosol Characterization Experiment (LACE) (Ansmann et al., 1998), the Saharan mineral dust experiments, SAMUM-1 (Heintzenberg, 2009) and SAMUM-2 (Ansmann et al., 2011), the European integrated project on 
Table I. Mean values and mean systematic uncertainties for the intensive optical properties $S_{\mathrm{p}}$ and $\delta_{\mathrm{p}}$ of different aerosol types measured with WALES, MULIS and POLIS. Numbers in brackets give the number of measurements.

\begin{tabular}{|c|c|c|c|c|c|}
\hline Aerosol type & $\begin{array}{l}\text { WALES } \\
532 \mathrm{~nm}\end{array}$ & $\begin{array}{l}\text { MULIS } \\
532 \mathrm{~nm}\end{array}$ & $\begin{array}{l}\text { POLIS } \\
355 \mathrm{~nm}\end{array}$ & $\begin{array}{c}\text { Field } \\
\text { experiment }\end{array}$ & Reference \\
\hline \multicolumn{6}{|l|}{$S_{p}(s r)$} \\
\hline Saharan dust & $48 \pm 5(4)$ & $56 \pm 5^{\mathrm{a}}(13)$ & & SAMUM-I & Esselborn et al. (2009); Tesche et al. (2009) \\
\hline & & & $58 \pm 8(6)$ & SAMUM-2 & Groß et al. (201 la) \\
\hline Dust mixture & $50 \pm 4(5)$ & & $54 \pm 3(6)$ & SAMUM-2 & Groß et al. (201 la, 20।3b) \\
\hline ABB mixture & $63 \pm 7(5)$ & $69 \pm 8(13)$ & $76 \pm 12(12)$ & SAMUM-2 & Groß et al. (201 Ia, 20।3b) \\
\hline CBB & $69 \pm 17(1)$ & & & LACE98 & Groß et al. $(2013 b)$ \\
\hline Marine ${ }^{b}$ & $18 \pm 5(5)$ & $18 \pm 2(2)$ & $18 \pm 4(4)$ & SAMUM-2 & Groß et al. (20। Ia, 20।3b) \\
\hline Anthropogenic & $56 \pm 6(4)$ & & & EUCAARI & Groß et al. (20|3a) \\
\hline Volcanic ash & & $50 \pm 5(2)$ & $55 \pm 5(2)$ & Eyjafjalla & Groß et al. (2012) \\
\hline \multicolumn{6}{|l|}{$\delta_{\mathrm{p}}(\%)$} \\
\hline Saharan dust & $32 \pm 2(4)$ & $32 \pm 2(18)$ & $25 \pm 2(6)$ & $\begin{array}{l}\text { SAMUM-I } \\
\text { SAMUM-2 }\end{array}$ & $\begin{array}{l}\text { Esselborn et al. (2009); Freudenthaler et al. (2009) } \\
\text { Groß et al. (20। la) }\end{array}$ \\
\hline Dust mixture & $27 \pm 2(5)$ & $24 \pm 4(5)$ & $17 \pm 3(6)$ & SAMUM-2 & Groß et al. (201 Ia, 20।3b) \\
\hline ABB mixture & $14 \pm 2(5)$ & $16 \pm 1(13)$ & $16 \pm 3(12)$ & SAMUM-2 & Groß et al. (201 Ia, 20।3b) \\
\hline CBB & $7 \pm 2(1)$ & & & LACE98 & Groß et al. (2013b) \\
\hline Marine ${ }^{b}$ & $3 \pm 2(5)$ & $2 \pm 1(2)$ & $2 \pm 1(4)$ & SAMUM-2 & Groß et al. (20। Ia, 20।3b) \\
\hline Anthropogenic & $6 \pm 1(4)$ & & & EUCAARI & Groß et al. (20|3a) \\
\hline Volcanic ash & & $37 \pm 2(2)$ & $35 \pm 2(2)$ & Eyjafjalla & Groß et al. (2012) \\
\hline
\end{tabular}

ABB, African biomass burning; CBB, Canadian biomass burning.

${ }^{a}$ Coordinated ground-based measurements with the BERTHA system (Althausen et al., 2000) of TROPOS, Leipzig, as no Raman lidar measurements were performed with MULIS during SAMUM-I. Both systems were located next to each other in a horizontally very homogeneous atmosphere.

${ }^{b}$ Relative humidity in the marine aerosol layer $\geq 50 \%$.

Aerosol Cloud Climate and Air Quality Interactions (EUCAARI) (Kulmala et al., 2009), and the Eyjafjalla volcanic ash measurements at Munich university (Groß et al., 2012; Wiegner et al., 2012). During these field experiments, aerosol properties have been studied by an extensive set of aerosol in situ instruments on board the DLR Falcon research aircraft by an airborne HSRL system measuring the lidar ratio and the particle depolarization ratio at $532 \mathrm{~nm}$ and by two ground-based polarization sensitive Raman lidar systems of the Ludwig-Maximilians-Universität (LMU), München, operational at 532 and $355 \mathrm{~nm}$. For the volcanic ash measurements, no airborne HSRL measurements were performed. On the basis of this comprehensive dataset, we assess whether the aerosol classification scheme developed for $532 \mathrm{~nm}$ (Groß et al., 2013b) is applicable to future EarthCARE lidar measurements at $355 \mathrm{~nm}$. Although several studies on lidar derived aerosol optical properties have been performed, we restrict our comparisons to the above mentioned dataset to avoid uncertainties which might result from different instrument setups or combinations, or different calibration techniques. Furthermore, only few studies with simultaneously performed lidar measurements of the lidar ratio and the particle linear depolarization ratio at 355 and $532 \mathrm{~nm}$ together with in situ observations are reported in the literature so far. Discussions of the used dataset to former studies can be found in the references listed in Table 1. Information about the corresponding in situ measurements can be found in Groß et al. (2013b) and Weinzierl et al. (2011) and the references therein.

\subsection{Lidar systems}

In this section, we give a short overview of the lidar systems used to examine the wavelength dependence of $S_{\mathrm{p}}$ and $\delta_{\mathrm{p}}$ for different aerosol types. Details on instrument performance and measurement uncertainties are discussed in the corresponding references.

POLIS (Groß et al., 2008) is a ground-based small portable lidar system developed and operated by the Meteorological Institute of the LMU. Measurements were either performed in the depolarization mode, measuring the cross- and co-polarized lidar return at $355 \mathrm{~nm}$, or in the Raman mode measuring the elastically scattered signal return at $355 \mathrm{~nm}$ and the $\mathrm{N}_{2}$-Raman shifted return at $387 \mathrm{~nm}$.

MULIS (Freudenthaler et al., 2009) is a ground-based mobile multi-wavelength lidar system developed and operated by the Meteorological Institute of the LMU. It provides measurements of the elastically backscattered signals at 355, 532 (co- and cross-polarized) and $1064 \mathrm{~nm}$, and of the $\mathrm{N}_{2}$-Raman shifted signals at 387 and $607 \mathrm{~nm}$.

WALES (WAter vapor Lidar Experiment in Space) (Wirth et al., 2009), developed and operated by the DLR, is primarily an airborne differential absorption lidar (DIAL) system for water vapor measurements within the absorption band at $935 \mathrm{~nm}$ whose primary objective was the preparation of a space borne mission mapping the global water vapor distribution. Additional polarization sensitive aerosol channels at 532 and $1064 \mathrm{~nm}$ and a high spectral resolution capacity at $532 \mathrm{~nm}$ (Esselborn et al., 2008) enable simultaneous aerosol measurements. 


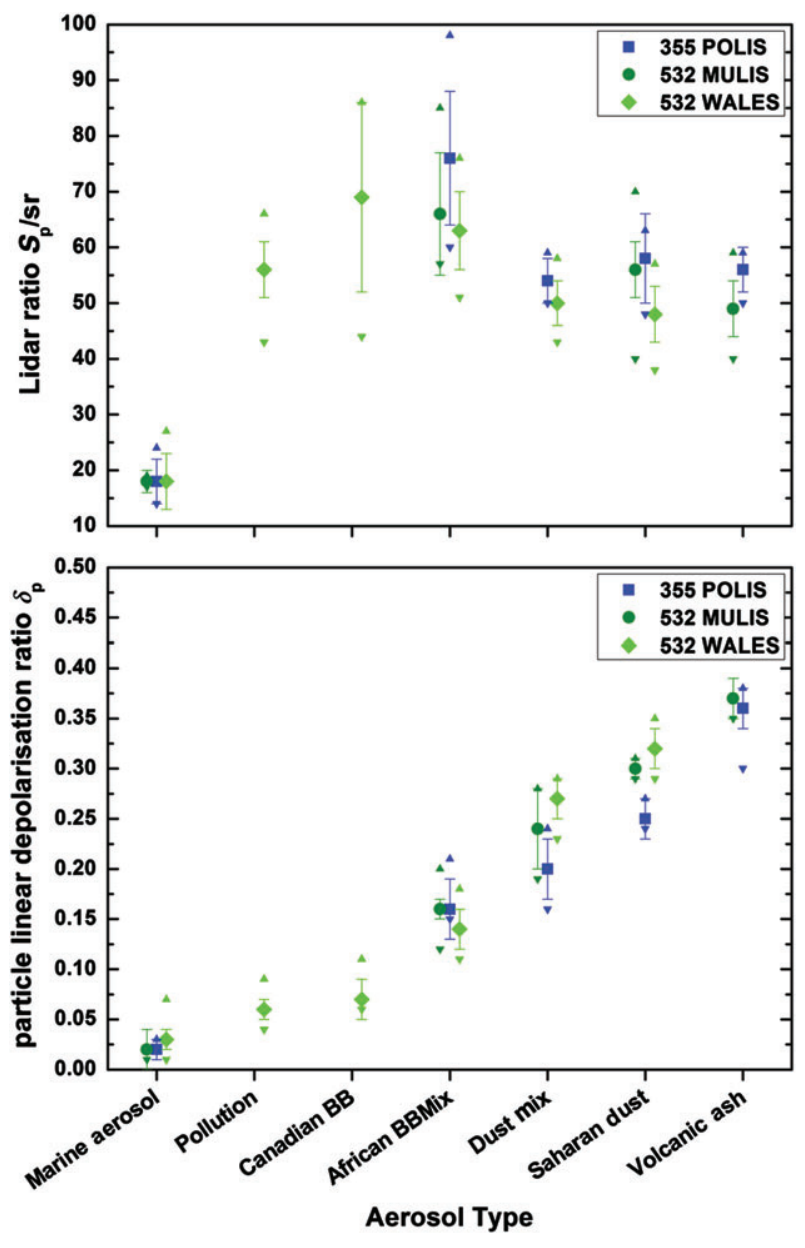

Figure I. Lidar ratio (top panel) and particle linear depolarization ratio (bottom panel) of the mean values found for the different aerosol types at 355 and $532 \mathrm{~nm}$ from POLIS $(355 \mathrm{~nm})$, MULIS and WALES (both $532 \mathrm{~nm}$ ) measurements. The error bars show the mean systematic uncertainties; the triangles show the maximum and minimum values.

\section{Results and discussion}

\section{I. Wavelength dependence of optical properties}

Figure 1 shows the mean values of the lidar ratio $S_{\mathrm{p}}$ and the particle linear depolarization ratio $\delta_{\mathrm{p}}$ for different aerosol types. The error bars indicate the mean systematic errors of these values. A general information about the error calculation of the different variables is given by Freudenthaler et al. (2009), Esselborn et al. (2008) and Groß et al. (2011b). The errors of the single measurements used for this work are discussed in corresponding references listed in Table 1 . No wavelength dependency of the lidar ratio is visible for marine aerosol, Saharan mineral dust and dust mixtures (Figure 1, top panel). For volcanic ash and African biomass burning mixtures, the mean $S_{\mathrm{p}}$ value at $355 \mathrm{~nm}$ is slightly higher than at $532 \mathrm{~nm}$, but considering the measurement uncertainties this difference is not significant. In the bottom panel of Figure 1, the particle linear depolarization ratio $\delta_{\mathrm{p}}$ is depicted for different aerosol types. No wavelength dependency for marine aerosol, African biomass burning mixtures and volcanic ash is

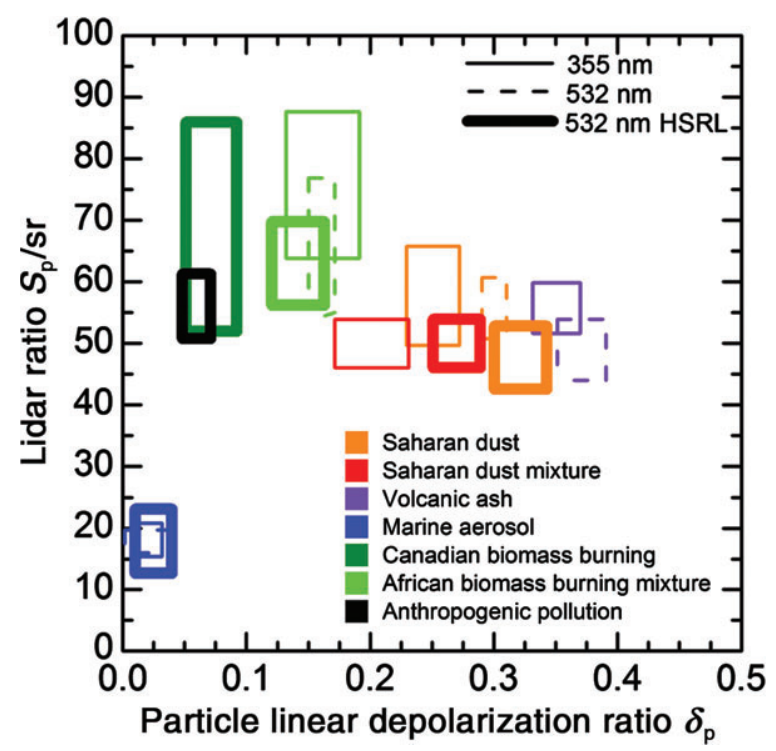

Figure 2. Aerosol lidar ratio versus particle linear depolarization ratio for various atmospheric aerosol types measured with the lidar systems POLIS at $355 \mathrm{~nm}$, and MULIS and WALES at $532 \mathrm{~nm}$. The rectangles denote the mean values plus/minus the mean uncertainties as summarized in Table I.

observed. In contrast, we find significantly lower values of $\delta_{\mathrm{p}}$ for Saharan dust at $355 \mathrm{~nm}$, and consequently also for dust mixtures at which it has to be kept in mind that $\delta_{\mathrm{p}}$ in dust mixtures dependents on the type and the amount of aerosol mixed with Saharan dust. In our case, we see a strong contribution of Saharan dust most probably mixed with marine aerosols, which is in good agreement to former findings (Mona et al., 2006). As we do not have coordinated $S_{\mathrm{p}}$ and $\delta_{\mathrm{p}}$ measurements at 355 and $532 \mathrm{~nm}$ for pure biomass burning aerosol and anthropogenic pollution airmasses from the three used lidar systems, the wavelength dependency for these two aerosol types will not be discussed here.

Table 1 summarizes the main findings of this section for the different aerosol types. Besides the values for $S_{\mathrm{p}}$ and $\delta_{\mathrm{p}}$ also the measurement uncertainties and the corresponding references are summarized.

\subsection{Classification scheme}

In this section, we discuss the applicability of the previously (Burton et al., 2012; Groß et al., 2013b) developed aerosol classification scheme at $532 \mathrm{~nm}$ for EarthCARE measurements at $355 \mathrm{~nm}$. Similar to Burton et al. (2012) and Groß et al. (2013b), the intensive lidar optical parameters $\left(S_{\mathrm{p}}\right.$ and $\left.\delta_{\mathrm{p}}\right)$ are presented in a two-dimensional $S_{\mathrm{p}}-\delta_{\mathrm{p}}$ parameter space in Figure 2, which additionally shows the values for both wavelengths, 355 and $532 \mathrm{~nm}$, in one plot.

The cluster for marine aerosol agrees well for the different wavelengths, confirming the applicability of the classification thresholds derived by Groß et al. (2013b) at $532 \mathrm{~nm}$ also for $355 \mathrm{~nm}$. For volcanic ash and African biomass burning mixture the data clusters at both wavelengths overlap. However, the mean values and uncertainty ranges at both wavelengths differ. 


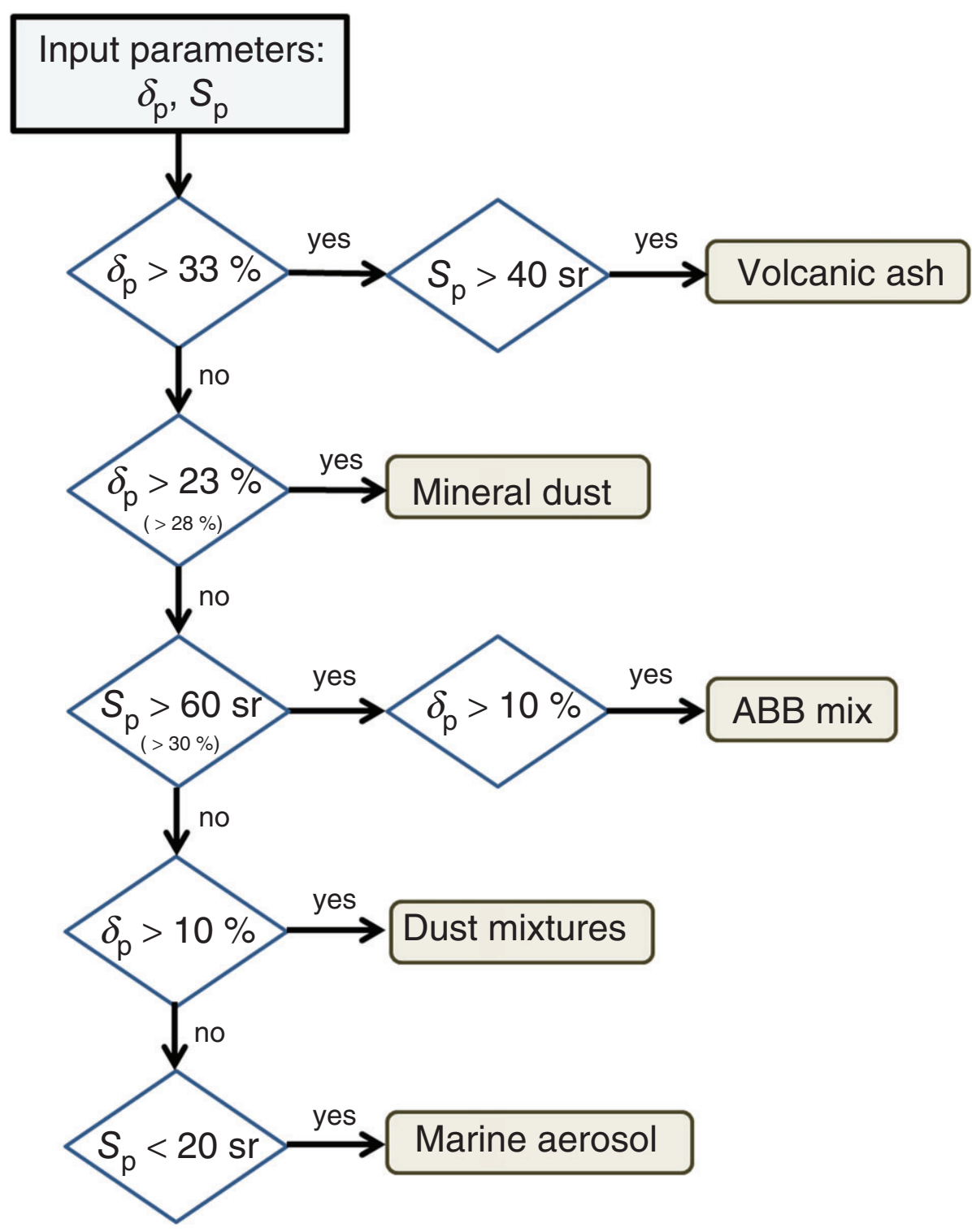

Figure 3. Schematic flowchart of the aerosol type classification based on lidar ratio $S_{\mathrm{p}}$ and particle linear depolarization ratio $\delta_{\mathrm{p}}$ information at $355 \mathrm{~nm}$; values at $532 \mathrm{~nm}$ [adapted from Groß et al. (20l3b)] are shown in brackets. ABB mix denotes African biomass burning mixtures.

For African biomass burning mixture the thresholds adapted by Groß et al. (2013b) retain $\left(S_{\mathrm{p}}>60 \mathrm{sr}\right.$ and $\left.\delta_{\mathrm{p}}>10 \%\right)$. For volcanic ash the thresholds for the aerosol classification scheme at $355 \mathrm{~nm}$ must be adapted to values higher $40 \mathrm{sr}$ for $S_{\mathrm{p}}$ and $33 \%$ for $\delta_{\mathrm{p}}$. The same holds for Saharan dust, were we do not see an overlap of the data clusters at all. The thresholds for the classification at $355 \mathrm{~nm}$ are $23 \%$ and $33 \%$ as lower and upper $\delta_{\mathrm{p}}$ values, respectively, and $60 \mathrm{sr}$ as upper threshold for $S_{\mathrm{p}}$.

Figure 3 presents the adapted aerosol type classification thresholds for lidar measurements (e.g. by ATLID on EarthCARE) at $355 \mathrm{~nm}$ on the basis of the results of this study. Using this classification scheme, it has to be kept in mind that some aerosol types show only small differences in the lidar optical properties (see Figures 1 and 2) and therefore they are harder to distinguish than other aerosol types. In addition, highly accurate lidar measurements with small uncertainties are necessary for correct aerosol type classification.

\subsection{Discussion}

The optical properties of aerosols are correlated with the aerosols microphysical properties like particle size, particle shape and chemical composition (Gasteiger et al., 2011). During short- to long-range transport, the microphysical properties can be modified by various mechanisms (Weinzierl et al., 2011), and with that the optical properties and the measurement values of $S_{\mathrm{p}}$ and $\delta_{\mathrm{p}}$ and their wavelength dependency can be influenced. For example, Amiridis et al. (2009) found from regular Raman lidar measurements that the values and wavelength dependence of the lidar ratio for biomass burning aerosols may change with time since emission. This may be caused by changing of the microphysical properties during transport. Another 
indication for the modification of optical properties during transport was found for mineral dust: during a strong Saharan dust outbreak in 2008 dual-wavelength depolarization measurements were performed over Central Europe (Wiegner et al., 2011). High $\delta_{\mathrm{p}}$ values of $30 \%$ were found at $355 \mathrm{~nm}$ compared to values of $25 \%$ during SAMUM-2. However, the measurements by Wiegner et al. (2011) cover only one case, and in addition, the dust load was very low resulting in large measurement uncertainties preventing a clear conclusion. More measurements of $S_{\mathrm{p}}$ and $\delta_{\mathrm{p}}$ in mineral dust plumes at different age after emission are necessary to draw final conclusions on changes of $S_{\mathrm{p}}$ and $\delta_{\mathrm{p}}$ as a result of aging processes.

Measurements of fresh and aged aerosol plumes, in particular of biomass burning aerosols and mineral dust, at different wavelengths are therefore crucial. Furthermore the aerosol classification scheme at $355 \mathrm{~nm}$ has to be extended for further basic aerosol types like anthropogenic pollution and cirrus clouds.

\section{Conclusion}

We presented a comparison of a comprehensive dataset of coordinated measurements with polarization sensitive Raman and HSRL lidar systems at 355 and $532 \mathrm{~nm}$ and examined the wavelength dependency of the lidar optical aerosol parameters, $S_{\mathrm{p}}$ and $\delta_{\mathrm{p}}$. On the basis of our analysis, we adapted the thresholds of the already existing aerosol classification scheme at $532 \mathrm{~nm}$ so that this classification scheme is applicable for future satellite lidar observations at $355 \mathrm{~nm}$ on board EarthCARE. Our study shows that for some aerosol types (e.g. marine aerosol) the classification thresholds found for $532 \mathrm{~nm}$ are also applicable at $355 \mathrm{~nm}$. For other aerosol types (e.g. mineral dust), the classification values have to be adapted for $355 \mathrm{~nm}$.

We see this study only as a starting point for an aerosol classification scheme at $355 \mathrm{~nm}$. Currently the dataset to develop a comprehensive classification scheme for global satellite lidar measurements at $355 \mathrm{~nm}$ is limited, especially with respect to different measurement locations and to aerosol mixtures. Thus questions concerning the influence of aerosol aging, natural variability, and complex aerosol mixtures on a global classification scheme cannot be answered yet. Future research activities are crucial to extend the database for aerosol type classification at $355 \mathrm{~nm}$. Especially, more measurements of basic aerosol types such as anthropogenic pollution or fresh biomass burning aerosol are necessary. In addition, special attention should be paid to the investigation of the effect of aerosol aging processes on the lidar optical parameters $S_{\mathrm{p}}$ and $\delta_{\mathrm{p}}$ at $355 \mathrm{~nm}$. Such investigations may result in different classification thresholds for fresh and aged aerosols of the same type. The Saharan Aerosol Long-Range TRansport and Aerosol Cloud interaction experiment (SALTRACE: http://www.pa.op.dlr.de/saltrace/) performed in June/July 2013 in the Caribbean may help to answer some of the aging-related questions. Furthermore, model calculations using complex particle shapes and in situ measurements as input parameters are helpful to study the sensitivity of the lidar optical properties $S_{\mathrm{p}}$ and $\delta_{\mathrm{p}}$ on the different microphysical properties.

\section{Acknowledgements}

This work has been funded partly by the HALO-SPP (No. 1294/2) under contract Nr. KI1567/1-1, and by the Helmholtz Association (VH-NG-606, Helmholtz-HochschulNachwuchsforschergruppe AerCARE).

\section{References}

Althausen D, Mueller D, Ansmann A, Wandinger U, Hube H, Clauder E, Zoerner S. 2000. Scanning six-wavelength eleven-channel aerosol lidar. Journal of Atmospheric and Oceanic Technology 17: 1469-1482.

Amiridis V, Balis DS, Giannakaki E, Stohl A, Kazadzis S, Koukouli ME, Zanis P. 2009. Optical characteristics of biomass burning aerosols over southeastern Europe determined from UV-Raman lidar measurements. Atmospheric Chemistry and Physics 9(7): 2431-2440, doi: 10.5194/acp-9-2431-2009.

Ansmann A, Wandinger U, Riebesell M, Weitkamp C, Michaelis W. 1992. Independent measurement of extinction and backscatter profiles in cirrus clouds by using a combined Raman elastic-backscatter lidar. Applied Optics 31(33): 7113-7131, doi: 10.1364/AO.31.007113.

Ansmann A, Wandinger U, Wiedensohler A, Leiterer U. 1998. Lindenberg aerosol characterization experiment 1998 (lace 98): overview. Journal of Geophysical Research 107(21): 8129, doi: 10.1029/2000JD000233.

Ansmann A, Petzold A, Kandler K, Tegen I, Wendisch M, Mueller D, Weinzierl B, Mueller T, Heintzenberg J. 2011. Saharan mineral dust experiments SAMUM1 and SAMUM2: what have we learned? Tellus B 63(4): 403-429, doi: 10.1111/j.1600-0889.2011.00555.x.

Bond TC, Doherty SJ, Fahey DW, Forster PM, Berntsen T, DeAngelo BJ, Flanner MG, Ghan S, Käarcher B, Koch D, Kinne S, Kondo Y, Quinn PK, Sarofim MC, Schultz MG, Schulz M, Venkataraman C, Zhang H, Zhang S, Bellouin N, Guttikunda SK, Hopke PK, Jacobson MZ, Kaiser JW, Klimont Z, Lohmann U, Schwarz JP, Shindell D, Storelvmo T, Warren SG, Zender CS. 2013. Bounding the role of black carbon in the climate system: a scientific assessment. Journal of Geophysical Research: Atmospheres 118(11): 5380-5552, doi: 10.1002/jgrd.50171.

Burton SP, Ferrare RA, Hostetler CA, Hair JW, Rogers RR, Obland MD, Butler CF, Cook AL, Harper DB, Froyd KD. 2012. Aerosol classification using airborne high spectral resolution lidar measurements methodology and examples. Atmospheric Measurement Techniques 5(1): 73-98, doi: 10.5194/amt-5-73-2012.

Burton SP, Ferrare RA, Vaughan MA, Omar AH, Rogers RR, Hostetler CA, Hair JW. 2013. Aerosol classification from airborne HSRL and comparisons with the CALIPSO vertical feature mask. Atmospheric Measurement Techniques 6(5): 1397-1412, doi: 10.5194/amt-6-1397-2013.

Esselborn M, Wirth M, Fix A, Tesche M, Ehret G. 2008. Airborne high spectral resolution lidar for measuring aerosol extinction and backscatter coefficients. Applied Optics 47(3): 346-358, doi: 10.1364/AO.47.000346.

Esselborn M, Wirth M, Fix A, Weinzierl B, Rasp K, Tesche M, Petzold A. 2009. Spatial distribution and optical properties of Saharan dust observed by airborne high spectral resolution lidar during SAMUM 2006. Tellus B 61(1): 131-143, doi: 10.1111/ j.1600-0889.2008.00394.x.

Forster P, Ramaswamy V, Artaxo P, Berntsen T, Betts R, Fahey DW, Haywood J, Lean J, Lowe DC, Myhre G, Nganga J, Prinn R, Raga G, Schulz M, Van Dorland R. 2007. Changes in atmospheric constituents 
and in radiative forcing. In Climate Change 2007: The Physical Science Basis. Contribution of Working Group I to the Fourth Assessment Report of the Intergovernmental Panel on Climate Change, Solomon S, Qin D, Manning M, Chen Z, Marquis M, Averyt KB, Tignor M, Miller HL (eds). Cambridge University Press: Cambridge, UK and New York, NY.

Freudenthaler V, Esselborn M, Wiegner M, Heese B, Tesche M, Ansmann A, Müller D, Althausen D, Wirth M, Fix A, Ehret G, Knippertz P, Toledano C, Gasteiger J, Garhammar M, Seefeldner M. 2009. Depolarization ratio profiling at several wavelengths in pure Saharan dust during SAMUM 2006. Tellus B 61(1): 165-179, doi: 10.1111/j.1600-0889.2008.00396.x.

Gasteiger J, Wiegner M, Groß S, Freudenthaler C, Toledano V, Tesche M, Kandler K. 2011. Modeling lidar-relevant optical properties of complex mineral dust aerosols. Tellus $B$ 63: 725-741, doi: 10.1111/j.1600-0889.2011.00559.x.

Groß S, Freudenthaler V, Toledano C, Seefeldner M, Wiegner M. 2008. Mini-lidar measurements of particle depolarization and Raman scattering of Saharan-dust and biomass burning at $355 \mathrm{~nm}$ during SAMUM 2. In Proceedings of 24th International Laser Radar Conference, Boulder, CO, 23-27 June 2008. S04P-10.

Groß S, Tesche M, Freudenthaler V, Toledano C, Wiegner M, Ansmann A, Althausen D, Seefeldner M. 2011a. Characterization of Saharan dust, marine aerosols and mixtures of biomass burning aerosols and dust by means of multi-wavelength depolarization- and Raman-measurements during SAMUM-2. Tellus B 63(4): 706-724, doi: 10.1111/j.1600-0889.2011.00556.x.

Groß S, Wiegner M, Freudenthaler V, Toledano C. 2011b. Lidar ratio of Saharan dust over Cape Verde Islands: assessment and error calculation. Journal of Geophysical Research 116: D15203, doi: 10.1029/2010JD015435.

Groß S, Freudenthaler V, Wiegner M, Gasteiger J, Geiß A, Schnell F. 2012. Dual wavelength linear depolarization ratio of volcanic aerosols: lidar measurements of the Eyjafjallajkull plume over Maisach, Germany. Atmospheric Environment 48: 85-96, doi: 10.1016/j.atmosenv.2011.06.017.

Groß S, Esselborn M, Abicht F, Wirth M, Fix A, Minikin A. 2013a. Airborne high spectral resolution lidar observation of pollution aerosol during EUCAARI-Longrex. Atmospheric Chemistry and Physics 13(5): 2435-2444, doi: 10.5194/acp-13-2435-2013.

Groß S, Esselborn M, Weinzierl B, Wirth M, Fix A, Petzold A. 2013b. Aerosol classification by airborne high spectral resolution lidar observations. Atmospheric Chemistry and Physics 13(5): 2487-2505, doi: 10.5194/acp-13-2487-2013.

Heintzenberg J. 2009. The SAMUM-1 experiment over southern Morocco: overview and introduction. Tellus B 61(1): 2-11, doi: 10.1111/j.1600-0889.2008.00403.x.

Kacenelenbogen M, Vaughan MA, Redemann J, Hoff RM, Rogers RR, Ferrare RA, Russell PB, Hostetler CA, Hair JW, Holben BN. 2011. An accuracy assessment of the CALIOP/CALIPSO version 2/version3 daytime aerosol extinction product based on a detailed multi-sensor, multi-platform case study. Atmospheric Chemistry and Physics 11(8): 3981-4000, doi: 10.5194/acp-11-3981-2011.
Kulmala M, Asmi A, Lappalainen HK, Carslaw KS, Pöschl U, Baltensperger U, Hov Ø, Brenquier J-L, Pandis SN, Facchini MC, Hansson H-C, Wiedensohler A, O'Dowd CD. 2009. Introduction: European integrated project on aerosol cloud climate and air quality interactions (EUCAARI) integrating aerosol research from nano to global scales. Atmospheric Chemistry and Physics 9(8): 2825-2841, doi: 10.5194/acp-9-2825-2009.

Mona L, Amodeo A, Pandolfi M, Pappalardo G. 2006. Saharan dust intrusions in the Mediterranean area: three years of Raman lidar measurements. Journal of Geophysical Research 111: D16203, doi: 10.1029/2005JD006569.

Omar AH, Winker DM, Vaughan MA, Hu Y, Trepte CR, Ferrare RA, Lee K-P, Hostetler CA, Kittaka C, Rogers RR, Kuehn RE, Liu Z. 2009. The CALIPSO automated aerosol classification and lidar ratio selection algorithm. Journal of Atmospheric and Oceanic Technology 26: 1994-2014.

Penner JE, Andreae M, Annegarn H, Barrie L, Feichter J, Hegg D, Jayaraman A, Leaitch R, Murphy D, Nganga J, Pitari G. 2001. Climate Change 2001: The Scientific Assessment. Cambridge University Press: New York, NY, 289-348.

Penner JE, Xu L, Wang M. 2011. Satellite methods underestimate indirect climate forcing by aerosols. Proceedings of the National Academy of Sciences 108(33): 13404-13408, doi: 10.1073/pnas.1018526108.

Piironen P, Eloranta EW. 1994. Demonstration of a highspectral-resolution lidar based on an iodine absorption filter. Optics Letters 19(3): 234-236, doi: 10.1364/OL.19.000234.

Tesche M, Ansmann A, Müller D, Althausen D, Mattis I, Heese B, Freudenthaler V, Wiegner M, Esselborn M, Pisani G, Knippertz P. 2009. Vertical profiling of Saharan dust with Raman lidars and airborne HSRL in southern morocco during SAMUM. Tellus B 61(1): 144-164, doi: 10.1111/j.1600-0889.2008.00390.x.

Weinzierl B, Sauer D, Esselborn M, Petzold A, Veira A, Rose M, Mund S, Wirth M, Ansmann A, Tesche M, Gross S, Freudenthaler V. 2011. Microphysical and optical properties of dust and tropical biomass burning aerosol layers in the Cape Verde region an overview of the airborne in situ and lidar measurements during SAMUM-2. Tellus B 63(4): 589-618, doi: 10.1111/ j.1600-0889.2011.00566.x.

Wiegner M, Groß S, Freudenthaler V, Schnell F, Gasteiger J. 2011. The May/June 2008 Saharan dust event over Munich: intensive aerosol parameters from lidar measurements. Journal of Geophysical Research 116(D23): 213, doi: 10.1029/2011JD016619.

Wiegner M, Gasteiger J, Groß S, Schnell F, Freudenthaler V, Forkel R. 2012. Characterization of the Eyjafjallajkull ash-plume: potential of lidar remote sensing. Physics and Chemistry of the Earth Parts A/B/C 45-46: 79-86, doi: 10.1016/j.pce.2011.01.006.

Winker DM, Hunt WH, McGill MJ. 2007. Initial performance assessment of CALIOP. Geophysical Research Letters 34: L19803.

Wirth M, Fix A, Mahnke P, Schwarzer H, Schrandt F, Ehret G. 2009. The airborne multi-wavelength H2O-DIAL WALES: system design and performance. Applied Physics B: Lasers and Optics 96(1): 201-213, doi: $10.1007 / \mathrm{s} 00340-009-3365-7$. 